\title{
БЕЗПЛІДНІСТЬ ЯК ОСНОВНИЙ АСПЕКТ ПОРУШЕННЯ ГЕНЕРАТИВНОЇ ФУНКЦІї ЖІНОК 3 НЕАТИПОВОЮ ГІПЕРПРОЛІФЕРАТИВНОЮ ПАТОЛОГІЄЮ ЕНДОМЕТРІЯ
}

\author{
๑Н. Є. Горбань', І. Б. Вовк', Н. Г. Гойда², О. В. Линчак ${ }^{3}$ \\ ДУ «Інститут педіатрії, акушерства і гінекології імені академіка О. М. Лук'янової НАМн України»' \\ Національна медична академія післядипломної освіти імені П. Л. Шупика \\ ДУ «Інститут громадського здоров'я імені О. М. Марзєєва НАМн України»
}

PEзЮмЕ. Жіноча безплідність у багатьох країнах світу не має тенденції до зниження. Припускають, що порушення генеративної функції можуть бути пов'язаними з гіперпроліферативною патологією ендометрія.

Мета - аналіз показників безплідності у жінок України у 2010-2017 рр. та у обстежених в клініці пацієнток із проблемами гіперпроліферації ендометрія.

Матеріал і методи. Використано дані статистичної звітності МОЗ України та Державної служби статистики України, а також досліджено особливості генеративної функції 184 обстежених пацієнток з неатиповою гіперпроліферативною патологією ендометрія (НГПЕ), поділених на 3 групи: I ( $n=60)$ - 3 неатиповою гіперплазією ендометрія (НГЕ), II (n=62) - з поліпами тіла матки (ПТМ), III ( $n=62)$ - з поєднанням НГЕ+ПТМ.

Результати. Частота безплідності жінок в Україні становить 4,07 \%о. У пацієнток з НГПЕ та вторинною безплідністю по відношенню до наявних вагітностей відмічали меншу частка пологів, артифіціальних абортів та самовільних викиднів, порівняно із хворими з НГПЕ без діагнозу «безплідність». У 51,09 \% жінок з НГПЕ діагностували сальпінгіти, у 25,54 \% - спайковий процес органів малого таза, у 29,35 \% - первинну, у 16,30 \% - вторинну безплідність. Сальпінгіти та спайковий процес серед жінок з НГПЕ частіше траплялися у пацієнток з безплідністю, ніж у тих, хто не мав такого діагнозу.

Висновки. Видалення гіперпластично зміненої ендометріальної тканини із наступним патогенетично обґрунтованим лікуванням має стати стандартом надання допомоги на етапі прегравідарної підготовки такої когорти жінок.

КЛючОВІ СлОВА: безплідність; гіперпроліферативна патологія ендометрія; неатипова гіперплазія ендометрія; поліп тіла матки.

Вступ. Частота безплідних шлюбів у багатьох країнах світу не має тенденції до зниження. В Росії і США цей показник складає 8-15\%, у Європіприблизно $10 \%$, у Канаді - $17 \%$, в Ірані - $8 \%$, у Казахстані - близько $15 \%[1,2]$. Зі збільшенням віку відзначається зниження фертильності, яке розпочинається з 28 років і поступово зменшується до віку 35 років, після чого до 42-річного віку фертильні можливості стають набагато гіршими [18]. Природний місячний рівень запліднення складає майже $25 \%$ у віці від 20 до 30 років і зменшується до $10 \%$ у віці старше 35 років. 3 віком зростає частота ожиріння, соматичних і гінекологічних захворювань, що збільшує показники безплідності й невиношування вагітності $[3,4]$.

Жіноча безплідність та пов'язані з нею репродуктивні розлади можуть мати наслідки для жінок навіть поза репродуктивним здоров'ям. Так, у жінок з безплідністю спостерігається вищий показник психічних розладів та раку ендометрія, порівняно з загальною популяцією $[5,6]$. Досі відкрите питання щодо того, чи мають безплідні жінки підвищений ризик онкологічних змін молочної залози та яєчників $[7,8]$.

Згідно з науковими даними, у безплідних жінок високою $\epsilon$ частота поліпів тіла матки (ПТМ) від 11 до 45 \%, що перевищує показник у загаль- ній популяції $[19,20]$. У великому проспективному дослідженні 1000 жінок із безпліддям, які готувалися до проведення допоміжних репродуктивних технологій, частота ендометріальних поліпів склала $32 \%[9,10,11]$, що може свідчити про взаємозв'язок гіперпроліферативної патології ендометрія із таким порушенням генеративної функції. У ряді публікацій наголошується, що їх видалення позитивно впливає на зачаття у природних циклах, а також при застосуванні внутрішньоматкової інсемінації та допоміжних репродуктивних технологій $[9,12,13]$.

Зважаючи на гостроту вищевикладених питань щодо порушень жіночої репродуктивної функції, метою нашого дослідження став аналіз ситуації безплідності у жінок із проблемами гіперпроліферації. Для виконання мети виконували наступні завдання: оцінити рівень жіночої безплідності в Україні у територіальному розрізі та його зміну з плином часу й охарактеризувати генеративну функцію жінок з неатиповою гіперпроліферативною патологією ендометрія (НГПЕ).

Матеріал і методи дослідження. Проведено описове епідеміологічне дослідження суцільного типу з використанням статистичних даних за 2010-2017 рр. з поділом на чотирирічні періоди 2010-2013 та 2014-2017 рр. щодо безплідності на 
Огляди літератури, оригінальні дослідження, погляд на проблему, випадок з практики, короткі повідомлення території України. Факт відокремлення деяких українських територій (окупація території АР Крим, Донецької та Луганської областей) був врахований як систематична помилка при аналізі та оцінці отриманих результатів на цих територіях. Кількість жінок з безплідністю взята із збірників «Стан здоров'я жіночого населення в Україні» ДЗ «Центр медичної статистики МОЗ України». Фертильний вік обмежувався 18-49-річним періодом, дані згідно з Державною службою статистики України.

Проаналізована частота безплідності в Україні та областях шляхом аналізу розрахунку поширеності (prevalence proportion), проведений розрахунок відносного ризику (ВР) виникнення жіночої безплідності у 2010-2013 та 2014-2017 рр. в областях порівняно з Україною, і у 2014-2017 рр. порівняно з 2010-2013 рр. в Україні та у кожній окремій області.

Результати щодо розрахунку ВР картовані, де ВР з врахуванням 95 \% довірчого інтервалу визначався кольором: червоний - ВР перевищував 13 ймовірністю $95 \%$; блакитний - ВР менший 1 з ймовірністю 95 \%; білий - ВР не відрізнявся від 1 з ймовірністю $95 \%$.

Паралельно проаналізовані особливості становлення та перебігу генеративної функції у паці-

єнток репродуктивного віку з НГПЕ. Обстежено 184 пацієнтки відділення планування сім'ї та оперативної реабілітації репродуктивної функції жінок ДУ «Інститут педіатрії, акушерства і гінекології імені академіка О. М. Лук'янової НАМН України», у яких було діагностовано НГПЕ. Жінки були поділені на три групи: I групу складали пацієнтки 3 неатиповою гіперплазією ендометрія (НГЕ) (n=60); II групу - пацієнтки, які мали поліпи тіла матки (ПТМ) (n=62); до III групи увійшли хворі з поєднаною неатиповою гіперпроліферативною патологією ендометрія (ПНГПЕ) (поліпи тіла матки та неатипова гіперплазія ендометрія) ( $n=62)$. Сeредній вік жінок між групами не відрізнявся $((34,9 \pm 6,9),(33,0 \pm 5,7)$ та $(34,0 \pm 6,2)$ років відповідно, $p=0,52)$, що дозволило проводити зіставлення даних та наступний аналіз.

Результати й обговорення. Частота безплідності за 2010-2017 рр. складала $(4,07 \pm 0,01) \%$ серед 1000 жінок фертильного віку (рис. 1). Найбільше значення цього показника у Запорізькій області $((19,12 \pm 0,08) \%$, що у 12,5 раза відрізняється від найменшого значення у Луганській $((1,53 \pm 0,02) \%$ \%). Загалом по країні станом на 2017 р. близько 38 тис. жінок мали безплідність [22].

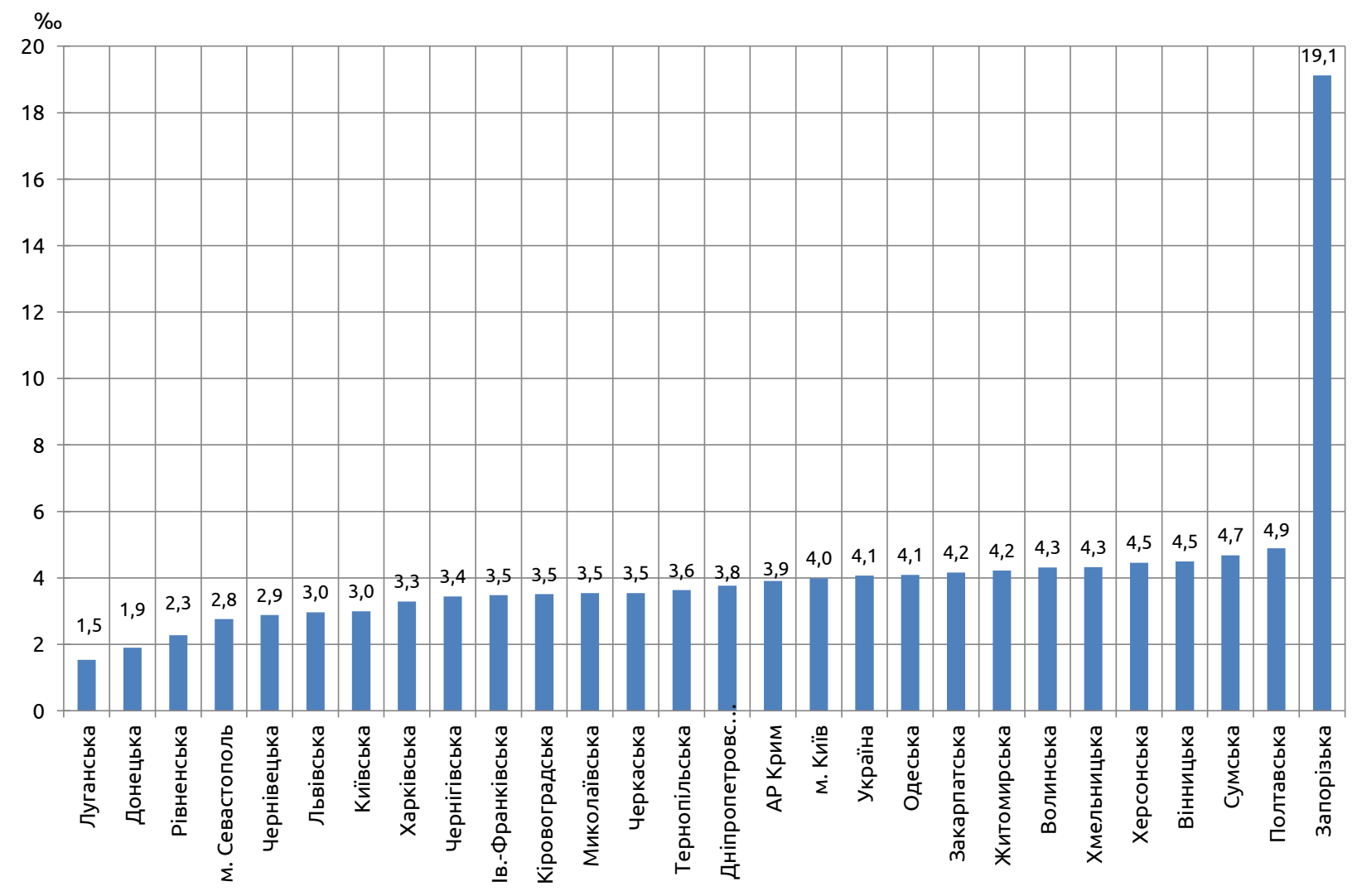

Рис. 1. Поширеність виникнення безплідності серед жінок фертильного віку (18-49 років) в областях України, 2010-2017 pp. 
Огляди літератури, оригінальні дослідження, погляд на проблему, випадок з практики, короткі повідомлення

Підвищення ВР виникнення безплідності у жінок фертильного віку за 2010-2013 рр. було відмічено лише на території шести областей, серед яких особливо виділяється Запорізька область із майже п'ятикратним підвищенням ВР $(4,74 ; 4,68-$ $4,80)$ (рис. 2). Ризик був підвищеним також у Одесь- кій $(1,02 ; 1,01-1,05)$, Житомирській $(1,06 ; 1,03-1,09)$, Херсонській $(1,08 ; 1,05-1,11)$, Волинській $(1,10$; 1,07-1,13), Вінницькій $(1,15 ; 1,12-1,18)$ областях. На усій іншій території він був зниженим, за винятком Полтавської та Сумської областей, де він не відрізнявся від загальноукраїнського показника.

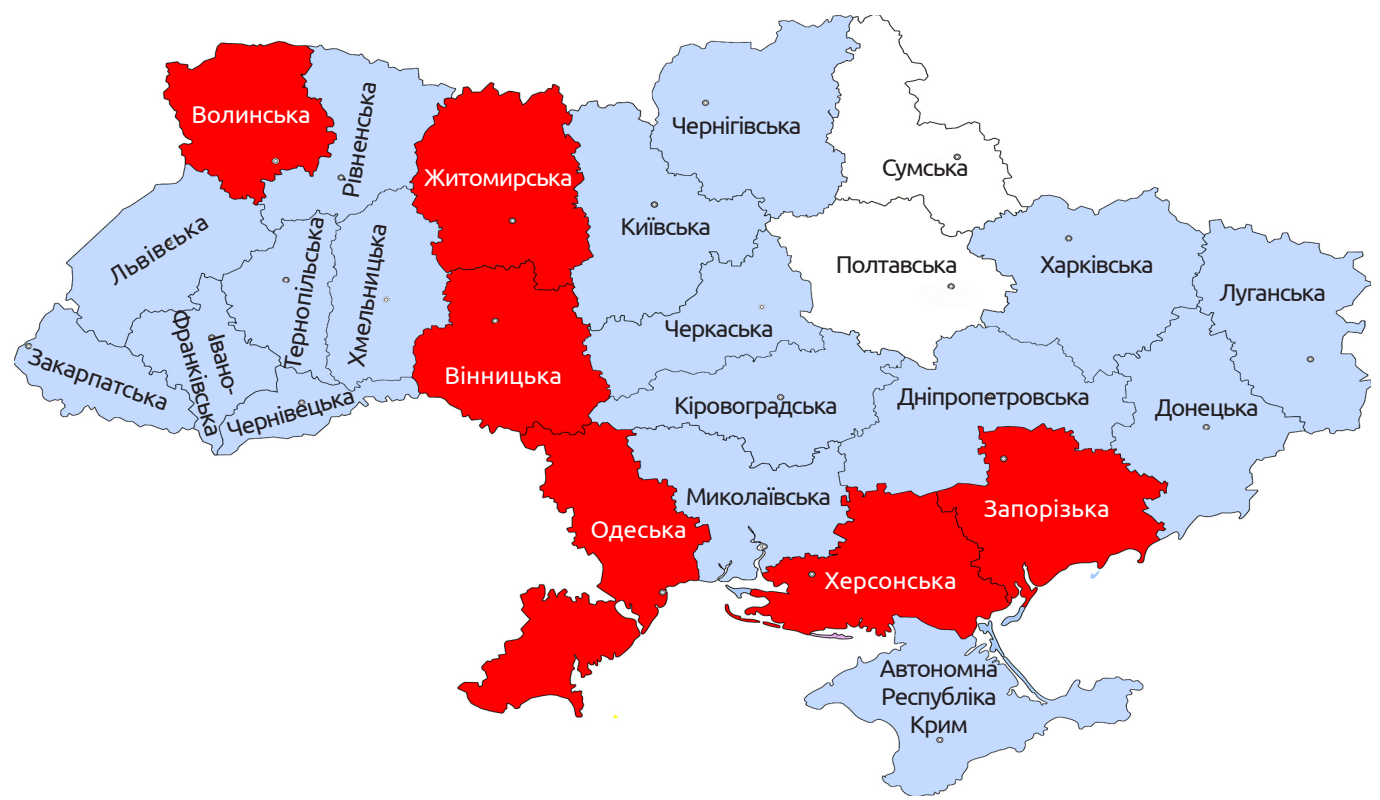

Рис. 2. Відносний ризик виникнення безплідності серед жінок фертильного віку (18-49 років) в областях порівняно з Україною, 2010-2013 рр. (м. Київ-0,93; 0,91-0,95; м. Севастополь- 0,67; 0,63-0,71).

У наступні 2014-2017 рр. підвищення ВР виникнення безплідності у жінок фертильного віку було відмічено на території семи областей та м. Києва (рис. 3) з найвищими значеннями підвищеного ВР у Запорізькій області $(6,50 ; 6,42-6,58)$.
Підвищення ВР було у Полтавській $(1,45 ; 1,41-$ $1,48)$, Сумській $(1,31 ; 1,27-1,34)$, Хмельницькій $(1,17 ; 1,14-1,20)$, Херсонській $(1,12 ; 1,08-1,15)$, Закарпатській $(1,08 ; 1,05-1,11)$, Вінницькій $(1,06$; $1,03-1,09)$ областях та м. Київ $(1,03 ; 1,01-1,05)$, тоді

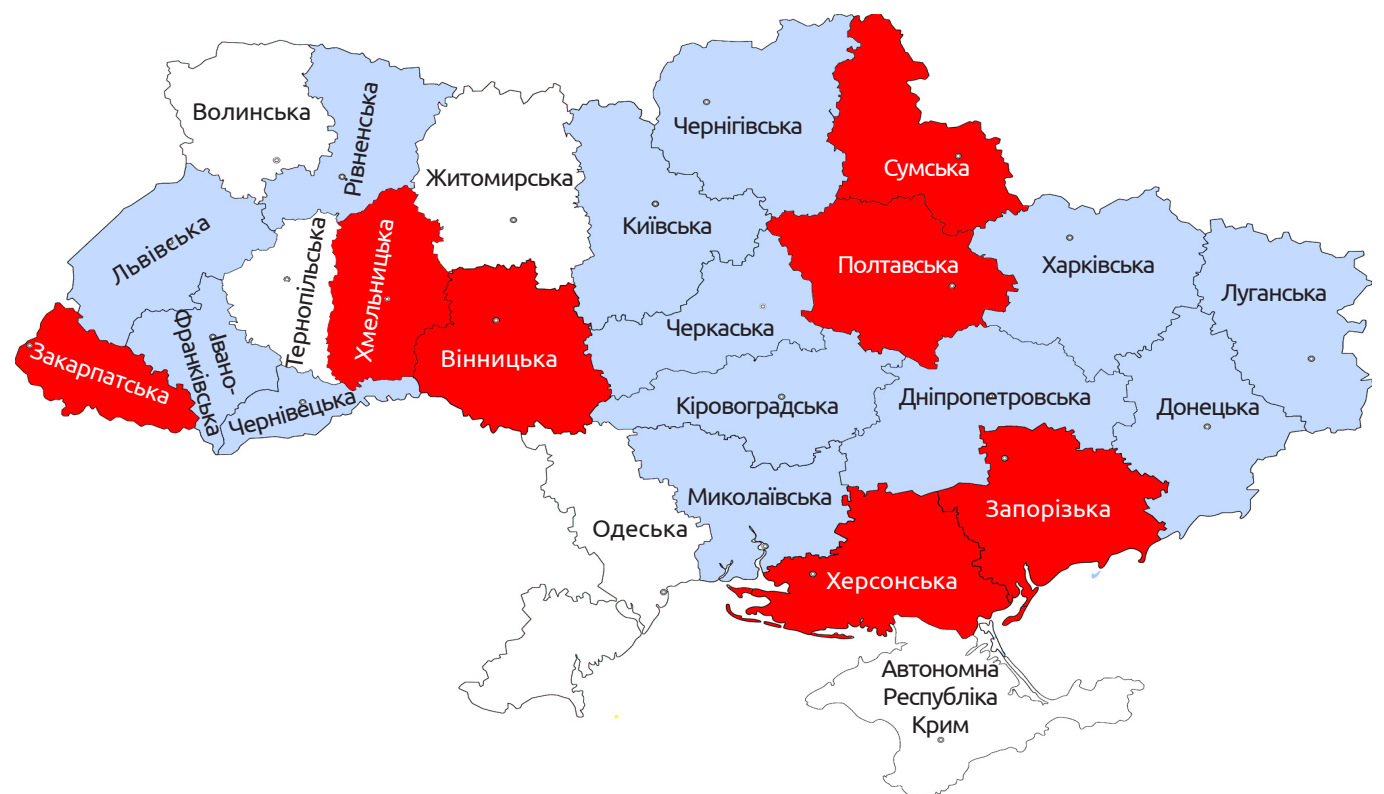

Рис. 3. Відносний ризик виникнення безплідності серед жінок фертильного віку (18-49 років) порівняно 3 Україною, 2014-2017рр. (Київ - 1,03; 1,01-1,05). 
Огляди літератури, оригінальні дослідження, погляд на проблему, випадок з практики, короткі повідомлення як на більшості території він був зниженим, за винятком Тернопільської, Одеської, Волинської і Житомирської областей, де вказаний показник не відрізнявся від загальноукраїнського. Слід також зазначити, що поряд з Донецькою $(0,22 ; 0,21-0,22)$ і Луганською $(0,11 ; 0,10-0,12)$ областями найменші значення ризику були відмічені у Рівненській $(0,48$;

$0,46-0,50)$, Чернівецькій $(0,65 ; 0,63-0,68)$, Харківській $(0,70 ; 0,69-0,72)$, Львівській $(0,71 ; 0,70-0,73)$, Київській $(0,75 ; 0,73-0,77)$ областях.

ВР виникнення безплідності у жінок фертильного віку в 2014-2017 рр., порівняно з 20102013 рр., в Україні був знижений $(0,99 ; 0,98-0,99)$, хоч і незначно (рис. 4).

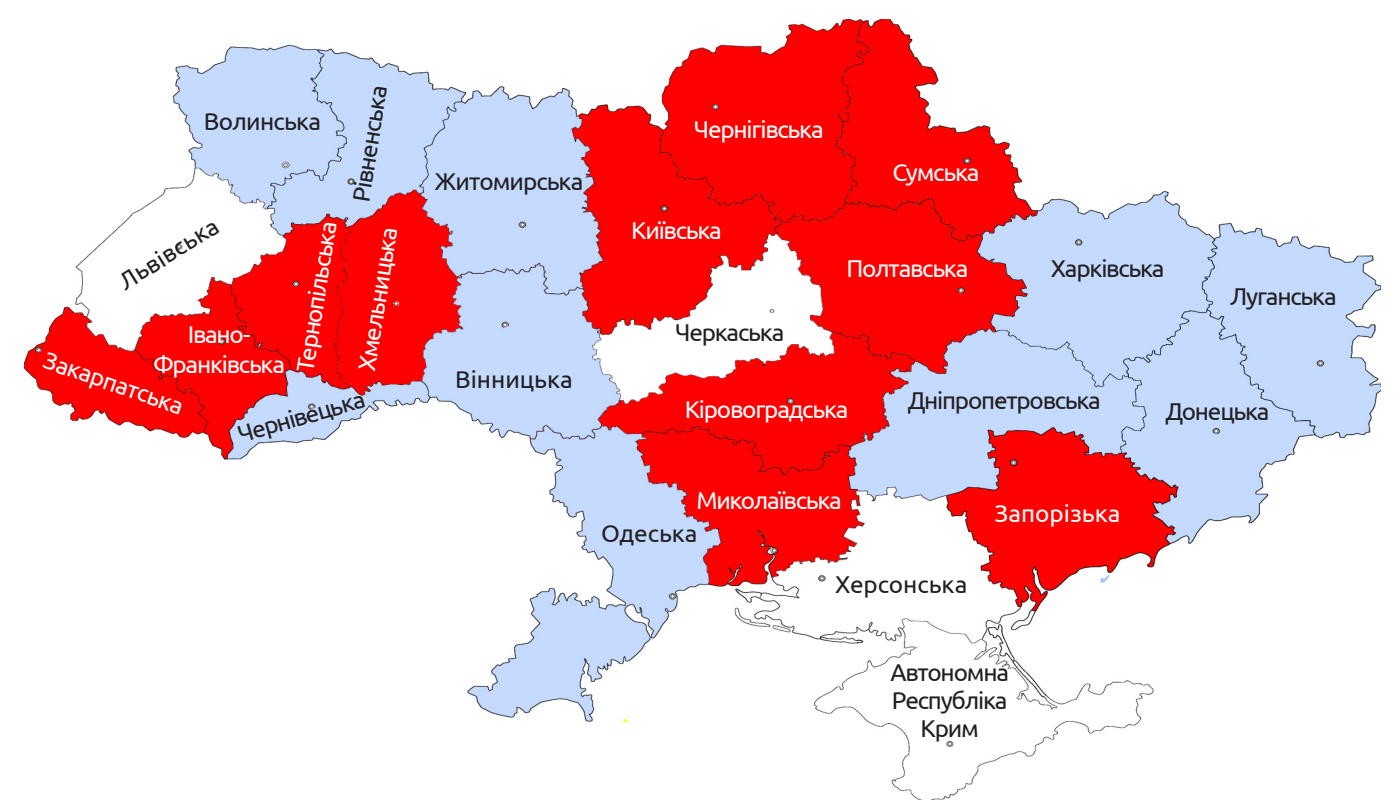

Рис. 4. Відносний ризик виникнення безплідності у жінок фертильного віку (18-49 років) в областях у 20142017 рр. порівняно з 2010-2013 рр. (Україна - 0,99; 0,98-0,99; м. Київ - 1,08; 1,05-1,11).

Поширеність жіночої безплідності в Україні до 2013 р. зростала, особливо з 2006 р. 32002 по 2012 р. таке зростання відмічалося в 1,35 раза (з $339,1 \pm 1,78$ до $459,1 \pm 2,17$ на 100 тис. жінок віком 15-44 років) [21]. Поясненням зниження показника в останні чотири роки може бути збільшення кількості пацієнтів з безплідністю, які звертаються за допомогою до приватних центрів репродукції, кількість яких також зростала.

У територіальному розрізі зниження показника відбулося лише на території 10 областей, на противагу 12, де він був підвищений. у Черкаській, Львівській і Херсонській областях показник 3 часом не змінився. Найсуттєвіше змінилися показники у Полтавській $(1,41 ; 1,36-1,46)$, Запорізькій $(1,27 ; 1,25-1,29)$, Сумській $(1,26 ; 1,21-1,32)$, Тернопільській $(1,19 ; 1,14-1,25)$, Хмельницькій $(1,19 ; 1,14-1,23)$ областях - значення ВР у 20142017 рр. порівняно з 2010-2013 рр. було найбільшим, та у Луганській $(0,19 ; 0,18-0,20)$, Донецькій $(0,34 ; 0,33-0,35)$, Рівненській $(0,76 ; 0,72-0,80)$, Харківській $(0,79 ; 0,77-0,82)$ - ВР у 2014-2017 рр., порівняно з 2010-2013 рр., був найменшим.

Згідно з дизайном нашого дослідження, в наступній частині розглянуті особливості генеративної функції у пацієнток з безплідністю за наяв- ності неатипової гіперпроліферативної патології ендометрія.

У пацієнток з НГПЕ первинна безплідність спостерігалась частіше, ніж вторинна $(29,35 \%$ проти $16,30 \%$, р<0,01). При розгляді окремо груп частота первинної безплідності була більш ніж удвічі вищою, ніж вторинної, у жінок з ПТМ $(25,81 \%$ проти $11,29 \%, p=0,06)$ та у жінок з поєднаною НГПЕ $(33,87$ \% проти $16,13 \%, \mathrm{p}=0,04)$ (табл. 1). Статистично достовірної різниці між частотою первинної та вторинної безплідності у групах дослідження між собою не було відмічено.

У кожної другої (51,09 \%) жінки з НГПЕ діагностувались сальпінгіти. Якщо поділити цих жінок за фактором безплідності, то можна помітити, що у кожної третьої жінки без діагнозу безплідності відмічались сальпінгіти (28,00 \%) проти 80 \% у жінок з безплідністю $(77,78$ \% з первинною та 80,00 \% - з вторинною). Найменше сальпінгітів виявлено у жінок із вторинною безплідністю та ПТМ (42,86 \%), тоді як найбільше - у жінок при поєднанні первинної безплідності з ПТМ (93,75 \%), вторинної безплідності з НГЕ (92,31 \%) та вторинної безплідності з поєднаною НГПЕ $(90,00 \%)$ (рис. 5). 
Огляди літератури, оригінальні дослідження, погляд на проблему, випадок з практики, короткі повідомлення Таблиця 1. Частота безплідності у жінок з неатиповою гіперпроліферативною патологією ендометрія, n (\%)

\begin{tabular}{|c|c|c|c|c|}
\hline \multirow[b]{2}{*}{ Клінічний діагноз } & \multicolumn{4}{|c|}{ Частота прояву, \% у жінок з } \\
\hline & $\begin{array}{c}\text { НГЕ } \\
\text { (І група) } \\
(n=60)\end{array}$ & $\begin{array}{c}\text { ПТМ } \\
\text { (II група) } \\
(n=62)\end{array}$ & $\begin{array}{c}\text { ПНГПЕ } \\
\text { (III група) } \\
\text { (n=62) }\end{array}$ & $\begin{array}{c}\text { НГПЕ } \\
\text { разом } \\
(n=184)\end{array}$ \\
\hline Безплідність первинна & $28,33 \pm 5,82$ & $25,81 \pm 5,56$ & $33,87 \pm 6,01$ & $29,35 \pm 3,36$ \\
\hline Безплідність вторинна & $21,67 \pm 7,52$ & $11,29 \pm 4,02$ & $16,13 \pm 4,67$ & $16,30 \pm 2,72$ \\
\hline Різниця, $\mathrm{P}$ & 0,52 & 0,06 & 0,04 & $<0,01$ \\
\hline
\end{tabular}

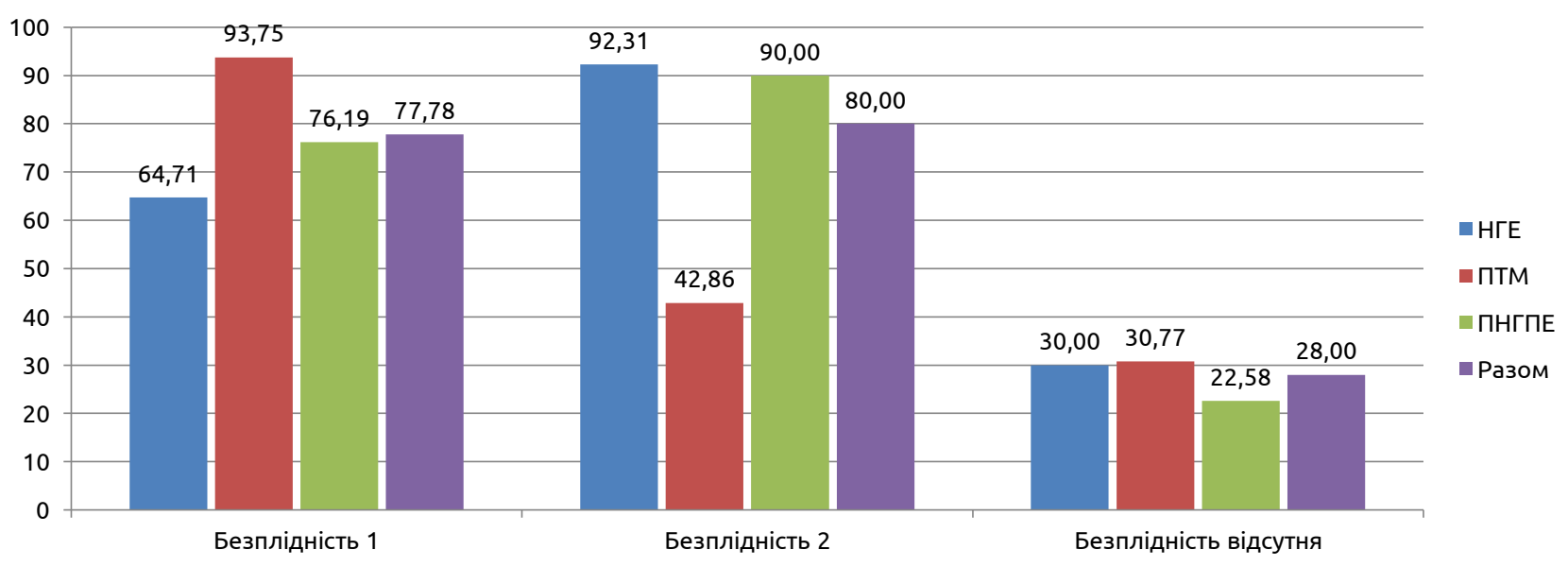

Рис. 5. Наявність сальпінгітів у жінок з безплідністю та неатиповою гіперпроліферативною патологією ендометрія, \%.

У кожної четвертої $(25,54$ \%) жінки з НГПЕ діагностували спайковий процес органів малого таза. Якщо поділити цих жінок за фактором безплідності, то показано, що найменша частка жі- нок зі спайками була у тих, хто не мав діагнозу безплідність (13,00 \%) проти тих, хто мав цю проблему (46,30 \% для первинної безплідності та 30,00 \% - для вторинної) (рис. 6).

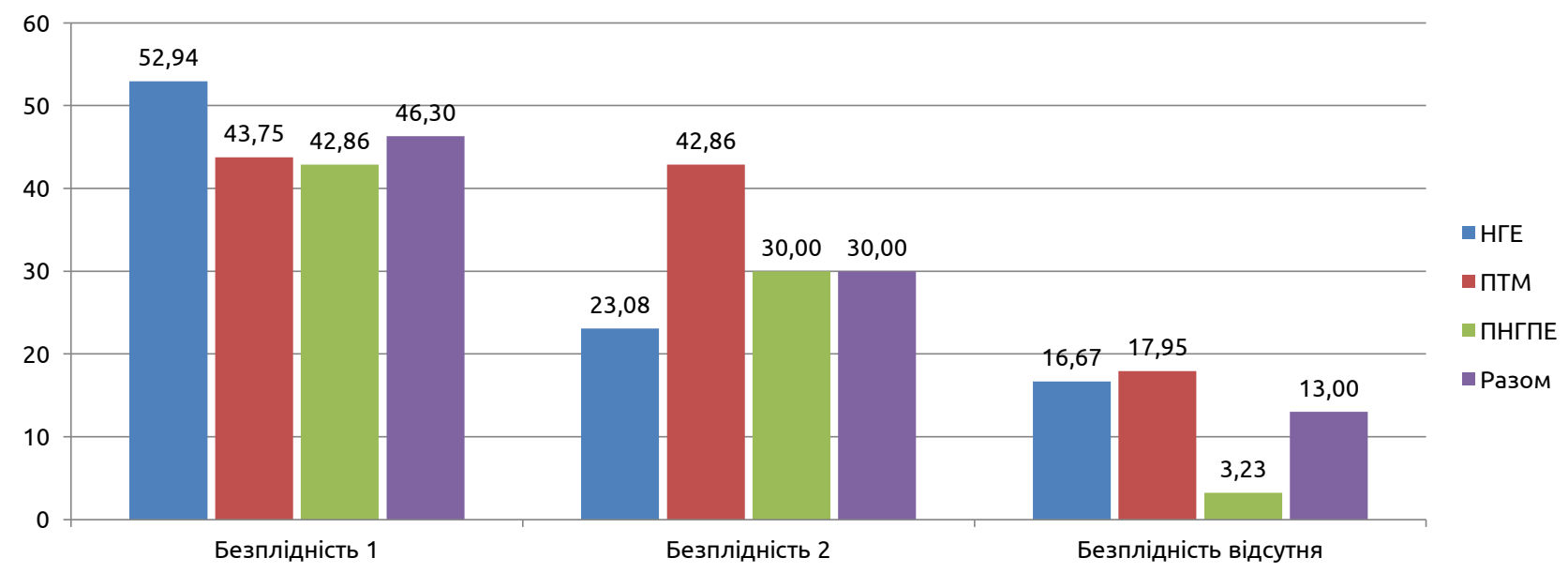

Рис. 6. Наявність спайкового процесу органів малого таза у жінок з безплідністю та неатиповою гіперпроліферативною патологією ендометрія, \%.

Тривалість первинної і вторинної безплідності (Б-1 і Б-2) у жінок була однаковою як загалом у групі з НГПЕ ((5,65 0,65$)$ проти $(4,38 \pm 0,68)$ років), так і у групах з ПТМ та з ПНГПЕ (табл. 2). Лише у 
Огляди літератури, оригінальні дослідження, погляд на проблему, випадок з практики, короткі повідомлення жінок з НГЕ первинна безплідність була триваліша, ніж вторинна $((6,47 \pm 1,46)$ проти $(2,77 \pm 0,43)$ років, $p=0,02)$. Між групами відмічалася лише більша тривалість вторинної безплідності серед жінок з поєднаною НГПЕ порівняно з жінками з НГЕ $((5,80 \pm 1,06)$ проти $(2,77 \pm 0,43)$ років). Найбільші максимальні значення тривалості безплідності відмічені у жінок з первинною безплідністю при наявності НГЕ та ПТМ (27 та 22 років відповідно), найменші максимальні значення - у жінок з НГЕ при вторинній безплідності (5 років).

Таблиця 2. Середня тривалість безплідності у пацієнток з неатиповою гіперпроліферативною патологією ендометрія, років

\begin{tabular}{|c|c|c|c|c|c|c|c|c|}
\hline \multirow{3}{*}{ Показник } & \multicolumn{8}{|c|}{ Жінки 3} \\
\hline & \multicolumn{2}{|c|}{ НГЕ } & \multicolumn{2}{|c|}{ ПтМ } & \multicolumn{2}{|c|}{ ПНГПЕ } & \multicolumn{2}{|c|}{ Разом } \\
\hline & Б-1 & Б-2 & Б-1 & Б-2 & Б-1 & Б-2 & Б-1 & $5-2$ \\
\hline Середнє значення & 6,47 & 2,77 & 5,50 & 5,36 & 5,10 & 5,80 & 5,65 & 4,38 \\
\hline Стандартна помилка & 1,46 & 0,43 & 1,36 & 2,24 & 0,65 & 1,06 & 0,65 & 0,68 \\
\hline Медіана & 5 & 2 & 3,5 & 2 & 6 & 5 & 5 & 3,5 \\
\hline Мода & 5 & 2 & 2 & 2 & 6 & 4 & 6 & 2 \\
\hline Стандартне відхилення & 6,01 & 1,54 & 5,44 & 5,94 & 2,96 & 3,36 & 4,79 & 3,72 \\
\hline Дисперсія вибірки & 36,14 & 2,36 & 29,60 & 35,23 & 8,79 & 11,29 & 22,95 & 13,86 \\
\hline Ексцес & 8,93 & $-1,27$ & 5,14 & 4,44 & $-1,08$ & $-1,07$ & 8,42 & 5,21 \\
\hline Асиметричність & 2,76 & 0,46 & 2,07 & 2,07 & 0,19 & 0,26 & 2,47 & 2,03 \\
\hline Мінімум & 1 & 1 & 1 & 1,5 & 1 & 1 & 1 & 1 \\
\hline Максимум & 27 & 5 & 22 & 18 & 10 & 11 & 27 & 18 \\
\hline
\end{tabular}

Примітка. Б-1 - первинна безплідність; Б-2 - вторинна безплідність.

Слід зазначити, що отримані нами дані збігаються з результатами іноземних робіт, на що вказують останні дослідження ролі ендометріальних поліпів у жінок, які планують вагітність [14]. Також деякі автори відмічають варіативність виявлення поліпів тіла матки у жінок, які перенесли процедуру екстракорпорального запліднення, від 6 до $32 \%[15,16]$. Щодо гіперплазій ендометрія та їх ролі у виникненні безплідності, цей показник має дещо нижчі цифри - 0,91\% [17].

Щодо генеративної функції пацієнток з НГПЕ, то на жінок з вторинною безплідністю та без визначеного діагнозу «безплідність» припадало більше двох вагітностей в анамнезі $(2,03 \pm 1,10$ та $2,26 \pm 1,49$ відповідно) (табл. 3). У цих межах перебувало значення середньої кількості вагітностей і у всіх досліджуваних групах, не відрізняючись між собою у жінок із вторинною безплідністю та без визначеного діагнозу «безплідність».

При розподілі по групах за НГПЕ відмічалася лише більша середня кількість вагітностей у групі жінок без діагнозу "безплідність», але при наявності НГЕ $((2,96 \pm 2,12)$ вагітностей) порівняно з такими ж жінками, але з ПТМ $(1,87 \pm 0,94, \mathrm{p}=0,02)$ та ПНГПЕ $(2,00 \pm 0,92, p=0,05)$.

Дві третини жінок, у яких була вторинна безплідність, мали в анамнезі пологи ((63,33 $\pm 8,80) \%)$, що значно менше, порівняно з жінками, які при наявності у них НГПЕ не мали діагнозу «безплідність» $((87,84 \pm 3,80) \%, p=0,007)$.

Серед жінок з вторинною безплідністю відмічається тенденція до зменшення частки вагітностей, які закінчилися пологами, у ряду НГЕ-ПТМПНГПЕ, а серед жінок без визначеного діагнозу «безплідність» виявлена протилежна ситуація. Окрім того, ця частка більша серед жінок без проблем з народженням дітей, на противагу жінкам із вторинною безплідністю (рис. 7).

Протилежна ситуація з самовільними викиднями. Частка вагітностей, які самовільно перервалися, серед жінок з вторинною безплідністю зростає у ряду НГЕ - ПТМ - поєднана НГПЕ, а серед жінок без визначеного діагнозу "безплідність», вона, навпаки, знижується. Окрім того, ця частка, відповідно, дво- та п'ятикратно більша серед жінок із вторинною безплідністю, на противагу жінкам без проблем з народженням дітей у групах жінок з поєднаною НГПЕ $((50,00 \pm 15,81) \%$ і $(10,00 \pm$ $6,71) \%$ при $\mathrm{p}=0,05)$ та у групі разом з НГПЕ $(40,00 \pm$

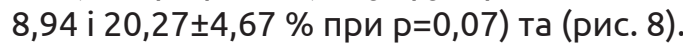

Якщо розглядати усіх жінок разом з НГПЕ, то артифіціальний аборт в анамнезі був відмічений у трьох з чотирьох жінок з вторинною безплідністю $((76,67 \pm 7,72) \%)$ проти кожної другої $((54,05 \pm 5,79) \%$ при $\mathrm{p}=0,05)$ жінки, які при наявності у них НГПЕ не мали діагнозу «безплідність». 
Огляди літератури, оригінальні дослідження, погляд на проблему, випадок з практики, короткі повідомлення

Таблиця 3. Середня кількість вагітностей у пацієнток з неатиповою гіперпроліферативною патологією ендометрія, вагітності

\begin{tabular}{|c|c|c|c|c|c|c|c|c|}
\hline \multirow{3}{*}{ Показник } & \multicolumn{8}{|c|}{ Жінки 3} \\
\hline & \multicolumn{2}{|c|}{ НГЕ } & \multicolumn{2}{|c|}{ ПтМ } & \multicolumn{2}{|c|}{ ПНГПЕ } & \multicolumn{2}{|c|}{ Разом } \\
\hline & $5-1$ & $5-2$ & $5-1$ & $5-2$ & 5-1 & $5-2$ & $5-1$ & 5-2 \\
\hline Середнє значення & 2,00 & 2,96 & 2,29 & 1,87 & 1,90 & 2,00 & 2,03 & 2,26 \\
\hline Стандартна помилка & 0,25 & 0,43 & 0,36 & 0,17 & 0,46 & 0,21 & 0,20 & 0,17 \\
\hline Медіана & 2 & 2 & 2 & 2 & 1 & 2 & 2 & 2 \\
\hline Мода & 3 & 1 & 2 & 1 & 1 & 2 & 1 & 1 \\
\hline Стандартне відхилення & 0,91 & 2,12 & 0,95 & 0,94 & 1,45 & 0,92 & 1,10 & 1,49 \\
\hline Дисперсія вибірки & 0,83 & 4,48 & 0,90 & 0,88 & 2,10 & 0,84 & 1,21 & 2,22 \\
\hline Ексцес & $-1,94$ & $-1,36$ & 1,24 & $-0,20$ & 1,39 & $-0,69$ & 0,35 & 1,33 \\
\hline Асиметричність & 0,00 & 0,63 & 0,86 & 0,82 & 1,58 & 0,45 & 0,93 & 1,41 \\
\hline Мінімум & 1 & 1 & 1 & 1 & 1 & 1 & 1 & 1 \\
\hline Максимум & 3 & 6 & 4 & 4 & 5 & 4 & 5 & 6 \\
\hline
\end{tabular}

Примітка. Б-1 - первинна безплідність; Б-2 - вторинна безплідність.

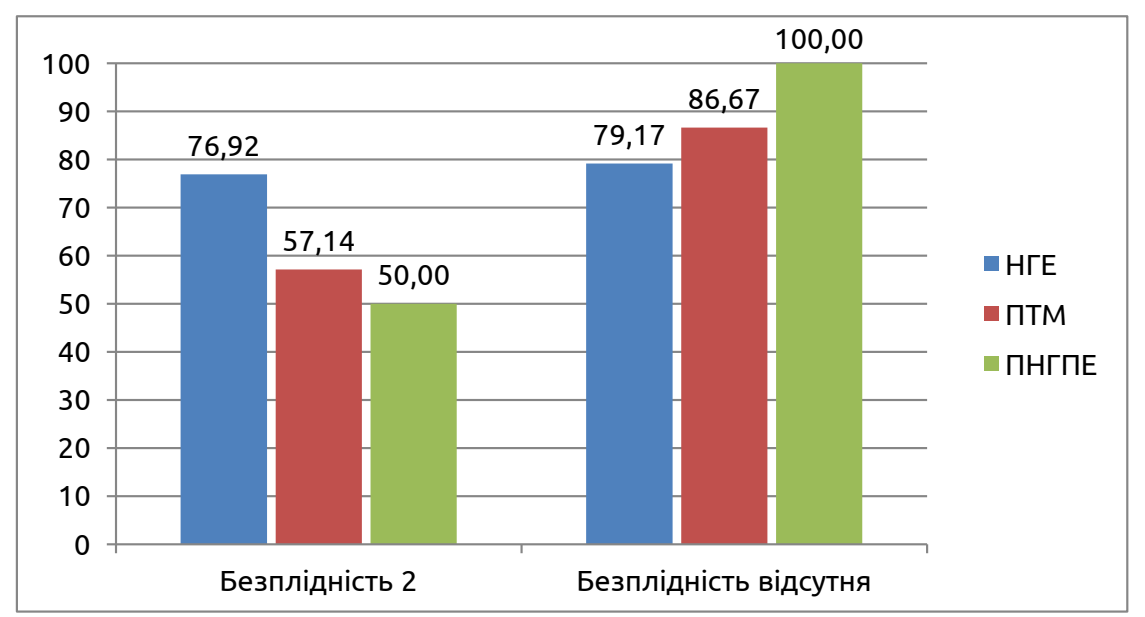

Рис. 7. Частка вагітностей, які закінчилися пологами, у пацієнток з неатиповою гіперпроліферативною патологією ендометрія, \%.

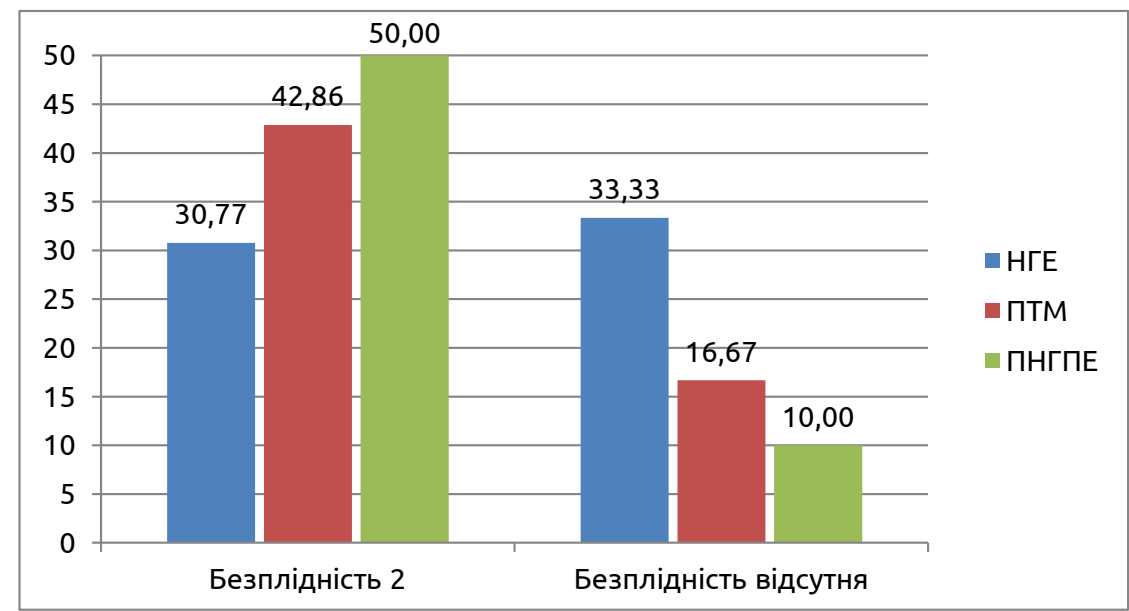

Рис. 8. Частка вагітностей, які закінчилися самовільними викиднями, у пацієнток з неатиповою гіперпроліферативною патологією ендометрія, \%. 
Огляди літератури, оригінальні дослідження, погляд на проблему, випадок з практики, короткі повідомлення

У всіх жінок з ПТМ та діагностованою вторинною безплідністю в анамнезі був артифіціальний аборт, тоді як у групі жінок з НГЕ та поєднаною НГПЕ цей показник становив 70 \% (рис. 9). Водночас серед жінок з НГПЕ, але без проблем з безплідністю, штучний аборт в анамнезі був лише у кожної другої. При цьому в розрізі всіх досліджуваних груп було показано більшу частоту артифіціальних абортів у жінок з вторинною безплідністю, хоча статистично значущою вона була лише у групі жінок з ПТМ $(100,00$ проти $(50,00 \pm 9,13) \%$ при $\mathrm{p}=0,05)$.

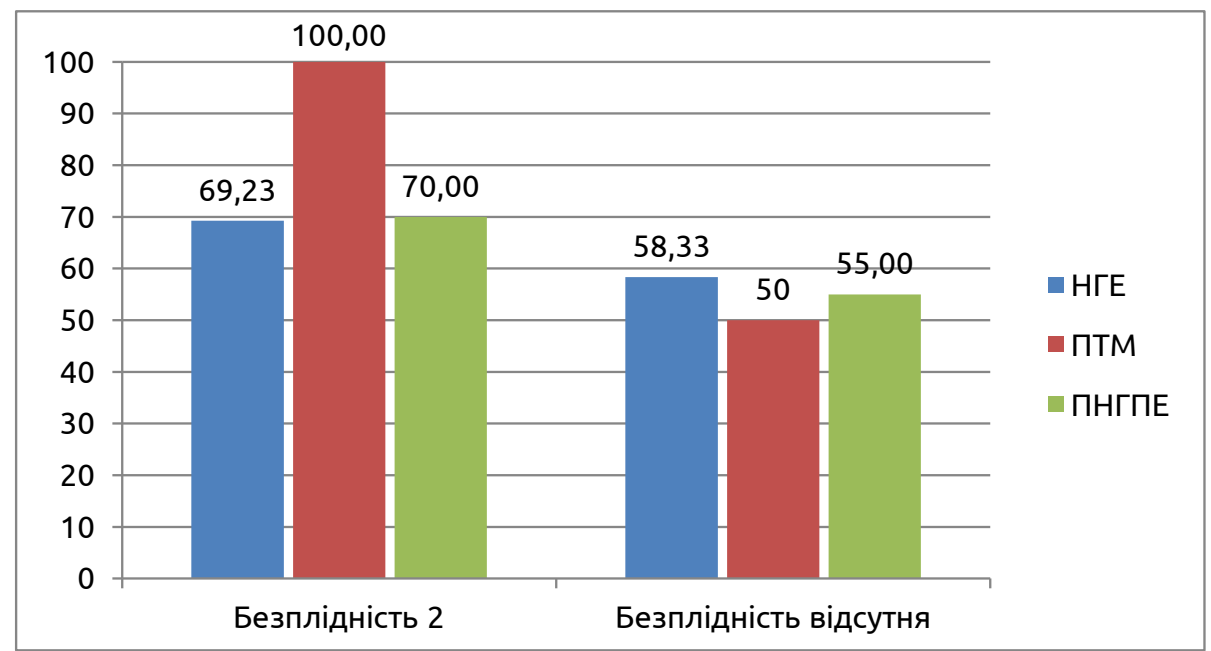

Рис. 9. Частка вагітностей, які закінчилися артифіціальним абортом, у пацієнток з неатиповою гіперпроліферативною патологією ендометрія, \%.

Вищевикладені дані дозволяють зробити висновок, що гінекологічний анамнез жінок 3 НГПЕ та діагностованою вторинною безплідністю більш обтяжений артифіціальними абортами та самовільними викиднями, порівняно $з$ жінками 3 НГПЕ, але без проблем з беплідністю.

На жаль, в літературі і досі немає єдиного погляду на роль гіперпроліферативної патології ендометрія в аспекті безплідності, автори не дійшли до чіткого алгоритму дій при таких клінічних обставинах, але наші дослідження та накопичений практичний досвід дозволяють стверджувати, що видалення гіперпластично зміненої ендометріальної тканини із наступним патогенетично обґрунтованим лікуванням пацієнтки повинно стати стандартом надання допомоги на етапі прегравідарної підготовки такої когорти жінок.

Висновки. 1. Частота безплідності у жінок в Україні за 2010-2017 рр. складала 4,07 \%о серед 1000 жінок фертильного віку.

2. У 2014-2017 рр. підвищення ВР виникнення безплідності у жінок фертильного віку було відмічено на території семи областей (Запорізька, Полтавська, Сумська, Хмельницька, Херсонська, Закарпатська, Вінницька) та м. Київ, тоді як на більшості території він був зниженим, за винятком Тернопільської, Одеської, Волинської і Житомирської областей, де він не відрізнявся від загальноукраїнського показника.

3. Відносний ризик виникнення безплідності у жінок фертильного віку в 2014-2017 рр., порів- няно $з$ 2010-2013 рр., в Україні був знижений $(0,99 ; 0,98-0,99)$, тоді як у територіальному розрізі зниження показника було виявлено на території 10 областей на противагу 12, де він виявився підвищеним.

4. У пацієнток з НГПЕ та вторинною безплідністю по відношенню до наявних вагітностей відмічалась менша частка пологів, артифіціальних абортів та самовільних викиднів ((63,33 $8,80) \%,(76,67 \pm 7,72) \%$ та $(40,00 \pm 8,94) \%)$, порівняно із хворими, які мали НГПЕ без діагнозу «безплідність» $((87,84 \pm 3,80) \%$ при $\mathrm{p}=0,007$, $(54,05 \pm 5,79) \%$ при $\mathrm{p}=0,05$ та $(20,27 \pm 4,67) \%$ при $\mathrm{p}=0,07$ відповідно).

5. У кожної другої $(51,09 \%)$ жінки з НГПЕ ді агностували сальпінгіти, у кожної четвертої (25,54 \%) - спайковий процес органів малого таза; безплідність первинна спостерігалась частіше, ніж вторинна ((29,35 $\pm 3,36) \%$ проти $(16,30 \pm 2,72) \%)$. Сальпінгіти та спайковий процес органів малого таза серед жінок з НГПЕ зустрічалися частіше у пацієнток з безплідністю, ніж у тих, хто не мав такого діагнозу.

6. Тривалість первинної і вторинної безплідності у жінок була однаковою як загалом у групі з НГПЕ $((5,65 \pm 0,65)$ років проти $(4,38 \pm 0,68)$ років), так і у групах окремо (з ПТМ та з ПНГПЕ) за винятком жінок з НГЕ. Між групами відмічалася лише більша тривалість вторинної безплідності серед

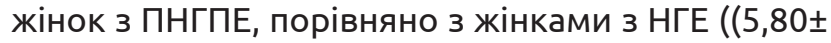
$1,06)$ років проти $(2,77 \pm 0,43)$ років). 
Огляди літератури, оригінальні дослідження, погляд на проблему, випадок з практики, короткі повідомлення

Перспективи подальших досліджень. Дослідження, виконані нами, продовжуються в плані зіставлення порушень генеративної функції та показника розвитку гіперпроліферативної патології жіночої репродуктивної сфери як причини безплідності.

\section{ЛІТЕРАТУРА}

1. Dupree J. M. Insurance coverage for male infertility care in the United States / J. M. Dupree // Asian J. Androl. - 2016. - Vol. 18 (3). - P. 339-341.

2. Obstetrics and gynecology residency and fertility needs: national survey results / L. Aghajanova, J. Hoffman, E. Mok-Lin, C. N. Herndon // Reprod. Sci. - 2017. - Vol. 24 (3). - P. 428-434.

3. Chandra A. Infertility service use in the United States: data from the National Survey of Family Growth, 1982-2010 / A. Chandra, C. E. Copen, E. H. Stephen // Natl Health Stat Report. - 2014. - Vol. 73. - P. 1-21.

4. Practice Committee of the American Society for Reproductive Medicine. Diagnostic evaluation of the infertile female: a committee opinion // Fertil. Steril. - 2015. Vol. 103. - P. e44-50.

5. Female infertility, infertility-associated diagnoses, and comorbidities: a review / B. Hanson, E. Johnstone, J. Dorais [et al.] // J. Assist. Reprod. Genet. - 2017. Vol. 34 (2). - P. 167-177.

6. Differences in psychophysical well-being and signs of depression in couples undergoing their first consultation for assisted reproduction technology (ART): an Italian pilot study / V. F. L. Valoriani, D. Lari, G. Miccinesi [et al.] // Europ J. Obstet. Gynecol. Reprod. Biol. - 2016. - Vol. 197. P. 179-185.

7. Barry J. Risk of endometrial, ovarian, and breast CA in women with polycystic ovarian syndrome: a systematic review and meta-analysis / J. Barry // Hum. Reprod. Update. - 2014. - Vol. 20 (5). - P. 748-758.

8. Brinton L. Fertility drugs and endometrial cancer risk: results from an extended follow up from a large infertility cohort / L. Brinton // Hum. Reprod. - 2013. - Vol. 28 (10). - P. 2813-2821.

9. Al Chami A. Endometrial Polyps and Subfertility / A. Al Chami, E. Saridogan // J. Obstet. Gynaecol. India. 2017. - Vol. 67 (1). - P. 9-14.

10. Prevalence of unsuspected uterine cavity abnormalities diagnosed by office hysteroscopy prior to in vitro fertilization / H. M. Fatemi, J. C. Kasius, A. Timmermans [et al.] // J. Hum. Reprod. - 2010. - Vol. 25 (8). P. 1959-1965.

11. Changes in the incidence and uptake of reproductive surgery versus in vitro fertilisation in Australia between 2001 and 2015: A population-based study / L. Foster,
S. J. Robson, A. Yazdani, P. Y. O'Shaughness // Aust. N. Z. J. Obstet. Gynaecol. - 2019. - Vol. 59. - P. 272-278.

12. Endometrial polyps and their implication in the pregnancy rates of patients undergoing intrauterine insemination: a prospective, randomized study / T. Perez-Medina, J. Bajo-Arenas, F. Salazar [et al.] // Hum. Reprod. 2005. - Vol. 20. - P. 1632-1635.

13. Shohayeb A. Persistent endometrial polyps may affect the pregnancy rate in patients undergoing intrauterine insemination / A. Shohayeb, A. Shaltout // Middle East Fertil. Soc. J. - 2011. - Vol. 16. - P. 259-264.

14. Al Chami A. Endometrial Polyps and Subfertility / A. Al Chami, E. Saridogan // J. Obstet. Gynaecol. India. 2017. - Vol. 67 (1). - P. 9-14.

15. Hinckley M. D. 1000 office-based hysteroscopies prior to in vitro fertilization: feasibility and findings / M. D. Hinckley, A. A. Milki // JSLS. - 2004. - Vol. 8. P. 103-107.

16. Prevalence of unsuspected uterine cavity abnormalities diagnosed by office hysteroscopy prior to in vitro fertilization / H. M. Fatemi, J. C. Kasius, A. Timmermans [et al.] // Hum. Reprod. - 2010. - Vol. 25. - P. 1959-1965. doi: 10.1093/humrep/deq150.

17. Histomorphological patterns of endometrium in infertility / S. S. Nandedkar, E. Patidar, D. B. Gada [et al.] // J. Obstet. Gynaecol. India. - 2015. - Vol. 65 (5). - P. 328-334.

18. Institut Marquès. The 5 stages of women's fertile life. News 2017. [Electronic resource]. URL: https://institutomarques.com/en/news/news-2017/ the-5-stages-of-womens-fertile-life/

19. Al Chami A. Endometrial polyps and subfertility / A. Al Chami, E. Saridogan // J. Obstet. Gynaecol. India. 2017. - Vol. 67 (1). - P. 9-14.

20. Management of endometrial polyps incidentally diagnosed during IVF: a case-control study / J. H. Yang, P. K. Yang, M. J. Chen [et al.] // Reprod. Biomed. Online. 2017. - Vol. 34 (3). - P. 285-290.

21. Генофонд і здоров'я: природний і штучний добір серед населення України / О. І. Тимченко, О. В. Линчак, Т. М. Поканєвич [та ін.]. - К. : Медінформ, 2015. - С. 35.

22. Стан здоров'я жіночого населення в Україні за 2017 рік / Міністерство охорони здоров'я України, ДЗ «Центр медичної статистики МОЗ України». - К., 2018. $228 \mathrm{c}$. 
Огляди літератури, оригінальні дослідження, погляд на проблему, випадок з практики, короткі повідомлення REFERENCES

1. Dupree, J.M. (2016). Insurance coverage for male infertility care in the United States. Asian J. Androl., 18 (3), 339-341.

2. Aghajanova, L. (2016). Obstetrics and gynecology residency and fertility needs: national survey results. Reprod. Sci., 24 (3), 428-434.

3. Chandra, A., Copen, C.E., \& Stephen, E.H. (2014). Infertility service use in the United States: data from the National Survey of Family Growth, 1982-2010. Natl. Health Stat. Report., 73, 1-21.

4. Practice Committee of the American Society for Reproductive Medicine. (2015). Diagnostic evaluation of the infertile female: a committee opinion. Fertil. Steril., 103, e44-50.

5. Hanson, B., Johnstone, E., Dorais, J., Silver, B., Peterson, C.M., \& Hotaling, J. (2017). Female infertility, infertility-associated diagnoses, and comorbidities: a review. J. Assist. Reprod. Genet., 34 (2), 167-177.

6. Valoriani, V.F.L., Lari, D., Miccinesi, G., Vaiani, S., Vanni, C., Coccia, M.E., ..., \& Noci, I. (2016). Differences in psychophysical well-being and signs of depression in couples undergoing their first consultation for assisted reproduction technology (ART): an Italian pilot study. Europ. J. Obstet. Gynecol. Reprod. Biol. 197, 179-185.

7. Barry, J. (2014). Risk of endometrial, ovarian, and breast CA in women with polycystic ovarian syndrome: a systematic review and meta-analysis. Hum. Reprod. Update, 20 (5), 748-758.

8. Brinton, L. (2013). Fertility drugs and endometrial cancer risk: results from an extended follow up from a large infertility cohort. Hum. Reprod., 28 (10), 2813-2821.

9. Al Chami, A., \& Saridogan, E. (2017). Endometrial Polyps and Subfertility. J. Obstet. Gynaecol. India, 67 (1), 9-14.

10. Fatemi, H.M., Kasius, J.C., Timmermans, A., van Disseldorp, J., Fauser, B.C., Devroey, P., \& Broekmans, F. (2010). Prevalence of unsuspected uterine cavity abnormalities diagnosed by office hysteroscopy prior to in vitro fertilization. J. Hum. Reprod. Aug., 25 (8), 1959-1965.

11. Foster, L., Robson, S.J., Yazdani, A. \& O'Shaughness, P.Y. (2019). Changes in the incidence and uptake of reproductive surgery versus in vitro fertilisation in Austraia between 2001 and 2015: A population-based study. Aust. N. Z. J. Obstet. Gynaecol., 59, 272-278.

12. Pérez-Medina, T., Bajo-Arenas, J., Salazar, F., Redondo, T., Sanfrutos, L., Alvarez, P., \& Engels, V. (2005). En-

dometrial polyps and their implication in the pregnancy rates of patients undergoing intrauterine insemination: a prospective, randomized study. Hum. Reprod., 20, 16321635.

13. Shohayeb, A., \& Shaltout, A. (2011). Persistent endometrial polyps may affect the pregnancy rate in patients undergoing intrauterine insemination. Middle East Fertil. Soc. J., 16, 259-264.

14. Al Chami, A., \& Saridogan, E. (2017). Endometrial Polyps and Subfertility. J. Obstet. Gynaecol. India, 67 (1), 9-14.

15. Hinckley, M.D., \& Milki, A.A. (2004). 1000 office-based hysteroscopies prior to in vitro fertilization: feasibility and findings. JSLS, 8, 103-107.

16. Fatemi, H.M., Kasius, J.C., Timmermans, A., van Disseldorp, J., Fauser, B.C., Devroey, P., \& Broekmans, F.J. (2010). Prevalence of unsuspected uterine cavity abnormalities diagnosed by office hysteroscopy prior to in vitro fertilization. Hum. Reprod., 25, 1959-1965. doi: 10.1093/ humrep/deq150.

17. Nandedkar, S.S., Patidar, E., Gada, D.B., Malukani, K., Munjal, K., \& Varma, A. (2015). Histomorphological Patterns of Endometrium in Infertility. J. Obstet. Gynaecol. India, 65 (5), 328-334.

18. Institut Marquès. The 5 stages of women's fertile life. News 2017. Retrieved from: https://institutomarques. com/en/news/news-2017/the-5-stages-of-womensfertile-life/

19. Al Chami, A., \& Saridogan, E. (2017). Endometrial polyps and subfertility. J Obstet. Gynaecol. India, 67 (1), 9-14.

20. Yang, J.H., Yang, P.K., Chen, M.J., Chen, S.U., \& Yang, Y.S. (2017). Management of endometrial polyps incidentally diagnosed during IVF: a case-control study. Reprod. Biomed. Online, 34 (3), 285-290.

21. Tymchenko, O.I., Lynchak, O.V., Pokanyevych, T.M. Protsyuk, O.V., Mykytenko, D.O., Kachko, H.O. ..., \& Horban, N.Ye. (2015). Henofond i zdorovia: pryrodnyi i shtuchnyi dobir sered naselennia Ukrainy [Gene pool and health: natural and artificial selection among the population of Ukraine]. Kyiv: Medinform [in Ukrainian].

22. (2018). Stan zdorovia zhinochoho naselennia v Ukraini za 2017 rik [State of woman health in Ukraine for 2017]. Kyiv: Ministerstvo okhorony zdorovia Ukrainy, DZ "Tsentr medychnoi statystyky MOZ Ukrainy" [in Ukrainian].

\section{БЕСПЛОДИЕ КАК ОСНОВНОЙ АСПЕКТ НАРУШЕНИЯ ГЕНЕРАТИВНОЙ ФУНКЦИИ У ЖЕНЩИН С НЕАТИПИЧЕСКОЙ ГИПЕРПРОЛИФЕРАТИВНОЙ ПАТОЛОГИЕЙ ЭНДОМЕТРИЯ} ОН. Е. Горбань' , И. Б. Вовк', Н. Г. Гойда², О. В. Линчак ${ }^{3}$ ГУ «Институт педиатрии, акушерства и гинекологии имени академика А. Н. Лукьяновой НАМн Украины» Национальная медицинская академия последипломного образования имени П. Л. Шупика² ГУ «Институт общественного здоровья имени А. Н. Марзеева НАМН Украины»»

РЕЗЮМЕ. Женское бесплодие во многих странах мира не имеет тенденции к снижению. Предполагают, что нарушения генеративной функции могут быть связаны с гиперпролиферативной патологией эндометрия. 
Огляди літератури, оригінальні дослідження, погляд на проблему, випадок з практики, короткі повідомлення

Цель - анализ показателей бесплодия у женщин Украины в 2010-2017 гг. и у обследованных в клинике пациенток с проблемами гиперпролиферации эндометрия.

Материал и методы. Использованы данные статистической отчетности Минздрава Украины и Государственной службы статистики Украины, а также исследованы особенности генеративной функции у 184 обследованных пациенток с неатипической гиперпролиферативной патологией эндометрия (НГПЭ), поделенных на 3 группы: I (n=60) - с неатипической гиперплазией эндометрия (НГЭ), II (n=62) - с полипами тела матки (ПТМ), III (n=62) - c сочетанием НГЭ + ПТМ.

Результаты. Частота бесплодия среди женщин в Украине составляла 4,07 \%о. У пациенток с НГПЭ и вторичным бесплодием по отношению к имеющимся беременностям отмечалась меньшая доля родов, артифициальних абортов и самопроизвольных выкидышей, по сравнению с больными с НГПЭ без диагноза «бесплодие». У $51,09 \%$ женщин с НГПЭ диагностировали сальпингиты, у 25,54 \% - спаечный процесс органов малого таза, у 29,35 \% первичное бесплодие, у 16,30 \% - вторичное. Сальпингиты и спаечный процесс среди женщин с НГПЭ встречались чаще у пациенток с бесплодием, чем среди тех, кто не имел такого диагноза.

Выводы. Удаление гиперпластически измененной эндометриальной ткани с последующим патогенетически обоснованным лечением должно стать стандартом оказания помощи на этапе прегравидарной подготовки такой когорты женщин.

КЛЮЧЕВЫЕ СЛОВА: бесплодие; гиперпролиферативная патология эндометрия; неатипическая гиперплазия эндометрия; полип тела матки.

\title{
INFERTILITY AS A MAJOR ASPECT OF IMPAIRED GENERATIVE FUNCTION OF WOMEN WITH NON-ATYPICAL ENDOMETRIAL HYPERPROLIFERATIVE PATHOLOGY
}

\author{
@N. Ye. Gorban' ${ }^{1}$ I. B. Vovk' ${ }^{1}$, N. H. Hoida ${ }^{2}$, O. V. Lynchak ${ }^{3}$ \\ M. Lukianova Institute of Pediatrics, Obstetrics and Gynecology of the NAMS of Ukraine' \\ P. Shupyk National Medical Academy of Postgraduate Education ${ }^{2}$ \\ O. Marzeiev Institute of Public Health of the NAMS of Ukraine ${ }^{3}$
}

SUMMARY. Female infertility in many countries of the world does not tend to decline. It is suggested that disorders of generative function may be associated with hyperproliferative endometrial pathology.

The aim - analysis of infertility indicators in women of Ukraine in 2010-2017 and in patients examined in the clinic with problems of endometrial hyperproliferation.

Materials and Methods. The data of the statistical reports of the Ministry of Healthcare of Ukraine and the State Statistics Service of Ukraine were used, as well as peculiarities of generative function in 184 examined patients with nonatypical endometrial hyperproliferative pathology (NAEHP), divided into 3 groups: I ( $n=60)$ - non-atypical endometrial hyperplasia (NAEH) ( $n=62)$ - uterine body polyps (UBP), III $(n=62)$ - NAEH+UBP combination.

Results. The frequency of infertility among women in Ukraine was $4.07 \%$. Patients with NAEHP and secondary infertility with respect to existing pregnancies had a lower proportion of births, artificial abortions, and miscarriages compared to patients with NAEHP without a diagnosis of infertility. In $51.09 \%$ of women with NAEHP, salpingitis was diagnosed, in $25.54 \%$ - the adhesions of the pelvic organs, in $29.35 \%$ - the primary infertility, in $16.30 \%$ - the secondary. Salpingitis and adhesions among women with NAEHP were more common in patients with infertility than among those who did not have this diagnosis.

Conclusions. Removal of hyperplastically altered endometrial tissue followed by pathogenetic treatment should be the standard of care at the stage of pregravid preparation of such women.

KEY WORDS: infertility; hyperproliferative endometrial pathology; non-atypical endometrial hyperplasia; uterine body polyp.

Отримано 10.08.2019 